\title{
In vitro and cellular activities of the selected fruits residues for skin aging treatment
}

\author{
NATTAYA LOURITH ${ }^{1,2}$, MAYUREE KANLAYAVATTANAKUL ${ }^{1,2}$, PUXVADEE CHAIKUL ${ }^{1,2}$, \\ CHAISAK CHANSRINIYOM ${ }^{3,4}$ and PICHAPORN BUNWATCHARAPHANSAKUN ${ }^{4}$ \\ ${ }^{1}$ School of Cosmetic Science, Mae Fah Luang University, 57100, Chiang Rai, Thailand \\ ${ }^{2}$ Phytocosmetics and Cosmeceuticals Research Group, Mae Fah Luang University, 57100, Chiang Rai, Thailand \\ ${ }^{3}$ Department of Pharmacognosy and Pharmaceutical Botany, Faculty of Pharmaceutical \\ Sciences, Chulalongkorn University, 10330, Bangkok, Thailand \\ ${ }^{4}$ National Nanotechnology Center, National Science and Technology Development Agency, 12120, Pathum Thani, Thailand
}

Manuscript received on December 4, 2016, accepted for publication on April 3, 2017

\begin{abstract}
Peel extracts of litchi and rambutan, and that of tamarind seed coat were investigated in relation to their utility in skin-aging treatments. Standardized extracts of tamarind were significantly $(p<0.05)$ more efficient at $\mathrm{O}_{2}^{-}$- scavenging $\left(\mathrm{IC}_{50}=27.44 \pm 0.09\right)$ than those of litchi and rambutan $\left(\mathrm{IC}_{50}=29.57 \pm 0.30\right.$ and $39.49 \pm 0.52 \mu \mathrm{g} / \mathrm{ml}$, respectively) and the quercetin standard $\left(\mathrm{IC}_{50}=31.88 \pm 0.15 \mu \mathrm{g} / \mathrm{ml}\right)$. Litchi extract proved significantly $(p<0.05)$ more effective for elastase and collagenase inhibition $(88.29 \pm 0.25 \%$ and $79.46 \pm 0.92 \%$, respectively) than tamarind $(35.43 \pm 0.68 \%$ and $57.69 \pm 5.97 \%)$ or rambutan $(31.08 \pm$ $0.38 \%$ and $53.99 \pm 6.18 \%$ ). All extracts were safe to human skin fibroblasts and inhibit MMP-2, with litchi extract showing significantly $(p<0.01)$ enhanced inhibition over the standard, vitamin C $(23.75 \pm$ $2.74 \%$ and $10.42 \pm 5.91 \%$ at $0.05 \mathrm{mg} / \mathrm{ml}$, respectively). Extracts suppress melanin production in B16F10 melanoma cells through inhibition of tyrosinase and TRP-2, with litchi extract being the most potent, even more so than kojic acid (standard). These results highlight the potential for adding value to agro-industrial waste, as the basis for the sustainable production of innovative, safe, anti-aging cosmetic products.
\end{abstract}

Key words: agro-industrial waste, antioxidant, cellular activities, cosmetics, enzyme inhibitions, fruit crop.

\section{INTRODUCTION}

Value creation from food supply chain wastes, in particular food residues, is an idea that is fueling new areas of research globally. Finding sustainable feedstocks based on waste for chemical and materials development, and new ways to

\footnotetext{
Correspondence to: Nattaya Lourith

E-mail: nattayal@mfu.ac.th

* Contribution to the centenary of the Brazilian Academy of Sciences.
}

transform wastes from fruit processing to valueadded products is of interest due to the low cost and abundance of biomass waste, and the diverse range of active chemical constituents locked within these waste materials. The inedible parts of fruits and vegetables from agro-businesses make up a large portion of such waste materials, the volume of which increases annually in line with demand for food products. Therefore, utilizing this waste as a source of new health product 
ingredients, such as phenolics or cosmetic actives, will add value to the food supply chain and streamline waste management processes due to lowering treatment and disposal costs (Matharu et al. 2016). Accordingly, the screening of byproducts from industrial crops for pharmaceutical actives, including cosmetic agents, is an area of considerable promise (Berto et al. 2015, Jorge et al. 2016, Lourith et al. 2016, Melo et al. 2015, Sung et al. 2015). Litchi (Litchi chinensis), rambutan (Nephelium lappaceum) and sweet tamarind (Tamarindus indica) are grown in abundance as fruit crops in Thailand (Kanlayavattanakul et al. 2012, Kanlayavattanakul and Lourith 2012, Pongpunyayuen and Lourith 2011). Utilizing waste from such crops as the basis for value-added materials (Melo et al. 2015) is challenging, but of considerable importance towards achieving the goal of zero-waste production (Matharu et al. 2016).

The peels of litchi and rambutan, and the seed coat of tamarind have been highlighted as important sources of antioxidant phenolics for use in healthcare products, including cosmetics (Kanlayavattanakul et al. 2012, Kanlayavattanakul and Lourith 2012, Pongpunyayuen and Lourith 2011). These fruit antioxidants exhibit significant ABTS (2,2'-Azino-bis(3-ethylbenzothiazoline)6-sulfonic acid) and DPPH (1,1-Diphenyl-2picrylhydrazyl) radical scavenging ability, superior to that of vitamin C.Additionally, their UV protective and anti-tyrosinase activities, in conjunction with non-cytotoxic nature in mammalian cell cultures (including human skin fibroblasts) widens their therapeutic utility, such as for use in skin hyperpigmentation treatments. Their potential in promoting human health is also enhanced due to their neuritogenic, and neuroprotective activities (Sarin et al. 2013).

Skin is composed of collagen and elastin, which are synthesized by fibroblast cells and act to regulate skin strength and elasticity. Reductions in fibroblast activities result in the sagging and wrinkling of skin. Matrix metalloproteinases (MMPs) are enzymes of the extracellular matrix (ECM) which take part in many degradation processes, including those of collagen and elastin. MMP activity is accelerated with age and in the presence of radicals, particularly superoxide anion $\left(\mathrm{O}_{2}{ }^{-}\right)$which is a potent inflammatory mediator (Herring and Jung 2012). Deactivation, inhibition or suppression of MMP, especially collagenase and elastase, are regarded as leading strategies in the management of skin aging (Kanlayavattanakul and Lourith 2015, Lourith and Kanlayavattanakul 2016). Therefore, employing antioxidants with enzyme inhibitory effects, notably radical scavenging phenolics, is common in anti-aging products formulations (Ranic et al. 2014). However, the down-regulation of fibroblasts correlates with up-regulation of melanocytes, resulting in dark spot formation, skin dehydration, and wrinkling (Kammeyer and Luiten 2015, Kanlayavattanakul et al. 2016). As a consequence, new products require testing against fibroblasts and melanoma cells to ensure confirmation of their safety and to assess the potency of the active constituents.

This study aims to assess the efficiencies of litchi, rambutan and tamarind residues as actives for preventing skin aging, through examining their radical (superoxide) scavenging abilities, and collagenase/elastase inhibitory effects. Assessments of antioxidant activities in fibroblasts, and melanogenesis inhibitory effects in B16F10 melanoma cells can provide an insight into extract safety.

\section{MATERIALS AND METHODS}

\section{MATERIALS}

All of the chemicals used were of analytical grade unless otherwise specified. The solvents for extraction, $n$-hexane, ethanol $(\mathrm{EtOH})$ and ethyl acetate (EtOAc), were from Merck 
(Germany). Deionized water was prepared using a Milli-Q water purification system (Millipore, USA). The chemicals and reagents for evaluating the antioxidant and enzyme inhibitory activities were from Sigma-Aldrich (USA), and those for the evaluation of the total phenolic contents were from Fluka (USA) as were the standards gallic acid, quercetin, ursolic acid and epigallocatechin gallate (EGCG). Those for cellular activity assessment were from Sigma-Aldrich, unless otherwise stated. The absorbance of each assay was recorded using a microplate reader (SPECTROstar Nano, BMG Labtech, Germany).

\section{SAMPLE PREPARATION}

The peels of litchi and rambutan and the seed coat of sweet tamarind (all cultivated in Chiang Rai) were collected. These fruit residues were washed in tap water and air-dried under the shade. The dried residues were thereafter oven dried (at $50^{\circ} \mathrm{C}$ ) and ground into powder, macerated in $70 \%$ EtOH followed by liquid-liquid extraction using $n$-hexane and EtOAc, stepwise. As delineated by the previous methods, the most potent extract was presented in the EtOAc fraction (Kanlayavattanakul and Lourith 2012, Kanlayavattanakul et al. 2012, Pongpunyayuen and Lourith 2011).

\section{TOTAL PHENOLIC CONTENT (TPC) ANALYSIS}

The total phenolic content in the peel extracts and seed coat extract was determined as previously described by Lourith et al. (2009) in a comparison with gallic acid using the Folin-Ciocalteu reagent. The results were reported in grams of gallic acid equivalent/100 $\mathrm{g}$ extract (g GAE/100 g extract).

\section{SUPEROXIDE ANION RADICAL SCAVENGING ACTIVITY}

The anion radicals were generated in Tris- $\mathrm{HCl}$ buffer $(16 \mathrm{mM}, \mathrm{pH}=8.0)$ in the presence of $78 \mu \mathrm{M}$ of reduced $\beta$-nicotinamide adenine dinucleotide (NADH), $50 \mu \mathrm{M}$ of nitroblue tetrazolim (NBT) and the test samples at various concentrations (15.63$500 \mu \mathrm{g} / \mathrm{ml}$ ). Phenazin methosulfate (PMS) with a concentration of $10 \mu \mathrm{M}$ was added into the reaction mixture, and the mixture was incubated under ambient conditions for $5 \mathrm{~min}$ prior to reading the absorbance at $560 \mathrm{~nm}$ (Berto et al. 2015, HakimeSilva et al. 2013). The radical terminating efficacy was compared with the standard quercetin. The antioxidant activities were assessed in triplicate.

\section{ELASTASE INHIBITORY EFFECT}

The protocol used was delineated by the reported protocol (Thring et al. 2009). Briefly, the reaction mixture containing Tris- $\mathrm{HCl}$ buffer $(0.2 \mathrm{mM}, \mathrm{pH}$ $=8.0)$, porcine pancreatic elastase $(\mathrm{PE}-$ E.C. 3.4 .21 .36 ) with a concentration of $3.33 \mathrm{mg} / \mathrm{ml}$ and $N$-succinyl-Ala-Ala-Ala- $p$-nitroaniline(AAAPVN) $(1.6 \mathrm{mM})$ was prepared. The absorbance of the mixture was monitored at $410 \mathrm{~nm}$ throughout the reaction, and after incubating the test sample for $20 \mathrm{~min}$, the absorbance was recorded. The enzyme inhibitory effect was compared with that of ursolic acid. The protocol was repeated three times for each sample.

\section{COLLAGENASE INHIBITORY EFFECT}

This enzyme assay was undertaken by the literature method (Thring et al. 2009). In short, tricine buffer (60 $\mathrm{mM}, \mathrm{pH}=7.5)$ was mixed with collagenase (ChC - E.C. 3.4.23.3) with a concentration of 0.8 units/ml and $2 \mathrm{mM}$ of $N$-[3-(2-furyl) acryloyl]Leu-Gly-Pro-Ala (FALGPA). The absorbance was recorded at $340 \mathrm{~nm}$ before and after incubation of the test sample with enzyme and FALGPA. The anti-collagenase activity was compared with EGCG. The assay was performed in triplicate. 


\section{ACTIVITY IN HUMAN FIBROBLASTS}

Human skin fibroblasts (ATCC ${ }^{\circledR}$ CRL 2097, USA) at $6-13^{\text {th }}$ passage were cultured in $75-\mathrm{cm}^{2}$ flask in Dulbecco's Modified Eagle's Medium (DMEM; Gibco, USA) medium supplemented with 10\% Fetal Bovine Serum (FBS; Gibco) and 1\% penicillin/ streptomycin (Gibco) at $37^{\circ} \mathrm{C}$ under $5 \% \mathrm{CO}_{2}$. Cells were grown and harvested by $0.25 \%$, w $/ v$ trypsin and $0.06 \mathrm{mM}$ EDTA in phosphate buffer saline.

The sulforhodamine B (SRB) assay was used for cell cytotoxicity determination. Cells $\left(1 \times 10^{4}\right.$ cells/well) were in 96-well plate and incubated for $24 \mathrm{~h}$, and treated with different concentrations of the samples for $72 \mathrm{~h}$. The adherent cells were fixed, washed and dyed prior to the absorbance measurement at $540 \mathrm{~nm}$ with the microplate reader. The cell viability was compared with the control (blank) treated with absolute ethanol (Kanlayavattanakul et al. 2016). Cell viability was calculated as following;

$$
\text { Cell viability }(\%)=\left[\mathrm{A}_{\text {sample }} / \mathrm{A}_{\mathrm{EtOH}}\right] \times 100
$$

where $\quad \mathrm{A}_{\text {sample }}=$ Absorbance of the sample $\mathrm{A}_{\mathrm{EtOH}}=$ Absorbance of the absolute ethanol

\section{INHIBITORY EFFECT AGAINST MATRIX} METALLOPROTEINASE-2 (MMP-2)

Fibroblasts ( $5 \times 10^{5}$ cells/well) in 6-well plate, cultivated without the supplement of FBS, were incubated for $24 \mathrm{~h}$. The cells were treated with the fruits' residue extracts by the non-cytotoxic doses and further incubated for $72 \mathrm{~h}$. The supernatant was collected for quantification of MMP-2 using SDS-PAGE zymography with gelatin as the substrate. The inhibitory effect was calculated in a comparison with those of the control, the supplement (Manosroi et al. 2011) as following;

$$
\begin{gathered}
\text { Inhibitory effect }(\%)=100-\left[\left(\mathrm{MMP}_{\text {sample }} /\right.\right. \\
\left.\left.\operatorname{MMP} 2_{\text {control }}\right) \times 100\right]
\end{gathered}
$$

where $\quad \mathrm{MMP}_{\text {sample }}=\mathrm{MMP}-2$ content of the sample $\mathrm{MMP} 2_{\text {control }}=\mathrm{MMP}-2$ content of the control

ANTI-MELANOGENESIS ACTIVITY IN B16F10 MELANOMA CELLS

B16F10 melanoma cells (ATCC ${ }^{\circledR}$ CRL 6475, USA) were cultured in $75-\mathrm{cm}^{2}$ flask in DMEM medium supplemented with $10 \%$ FBS and $1 \%$ penicillin/ streptomycin at $37{ }^{\circ} \mathrm{C}$ in a humidified incubator with $5 \% \mathrm{CO}_{2}$. Cells were grown to semiconfluence and harvested by $0.25 \%$, w/v trypsin and 0.06 mM EDTA in phosphate buffer saline. The SRB assay was used for cell cytotoxicity determination (Kanlayavattanakul et al. 2016) as above.

\section{MELANIN CONTENT MEASUREMENT}

Cells with a similar density as cytotoxicity assay were plated in 6-well plate and incubated for $24 \mathrm{~h}$ in the incubator. Samples at different concentrations, kojic acid (positive control), theophylline (negative control) and absolute ethanol (blank) were separately added and incubated for $72 \mathrm{~h}$ under the same condition. Melanin content was measured at $450 \mathrm{~nm}$ and total protein content was measured by means of Bradford assay. The relative ratio of melanin content was calculated (Kanlayavattanakul et al. 2016) as following;

Relative ratio of melanin content $(\%)=\left[\left(\mathrm{M}_{\text {sample }}{ }^{\prime}\right.\right.$

$$
\left.\left.\mathrm{P}_{\text {sample }}\right) /\left(\mathrm{M}_{\mathrm{EtOH}} / \mathrm{P}_{\mathrm{EtOH}}\right)\right] \times 100
$$

where $\mathrm{M}_{\text {sample }}=$ Melanin content of the sample

$\mathrm{M}_{\mathrm{EtOH}}=$ Melanin content of the absolute ethanol

$\mathrm{P}_{\text {sample }}=$ Protein content of the sample

$\mathrm{P}_{\mathrm{EtOH}} \quad$ Protein content of the absolute ethanol

\section{TYROSINASE ACTIVITY ASSESSMENT}

B16F10 melanoma $\left(5 \times 10^{5}\right.$ cells/well $)$ in 6 -well plate was incubated for $24 \mathrm{~h}$, treated with the samples or absolute ethanol and incubated for $72 \mathrm{~h}$. The treated cells were washed, lysed with RIPA buffer (Thermo Scientific, USA) containing 
protease inhibitor (Roche, Germany) and then incubated at $4{ }^{\circ} \mathrm{C}$ for $30 \mathrm{~min}$ before a centrifugation at 14,000 rpm (Universal $320 \mathrm{R}$, Hettich, Germany) for $10 \mathrm{~min}$. The supernatants were mixed with $0.05 \% \mathrm{~L}$-DOPA in $50 \mathrm{mM}$ phosphate buffer $(\mathrm{pH}$ 6.8) and incubated for $2 \mathrm{~h}$ at $37^{\circ} \mathrm{C}$. Tyrosinase activity was determined by means of DOPAchrome formation at $490 \mathrm{~nm}$. The enzyme activity was compared with the standard mushroom tyrosinase. The enzyme inhibitory effect was then calculated (Kanlayavattanakul et al. 2016) as following;

Enzyme inhibitory effect $(\%)=\left[\left(\mathrm{T}_{\text {sample }} / \mathrm{P}_{\text {sample }}\right) /\right.$ $\left.\left(\mathrm{T}_{\mathrm{EtOH}} / \mathrm{P}_{\mathrm{EtOH}}\right)\right] \times 100$

where $\mathrm{T}_{\text {sample }}=$ Tyrosinase activity of the sample $\mathrm{T}_{\mathrm{EtOH}}=$ Tyrosinase activity of the absolute ethanol

$\mathrm{P}_{\text {sample }}=$ Protein content of the sample

$\mathrm{P}_{\mathrm{EtOH}}=$ Protein content of the absolute ethanol

TYROSINASE RELATED PROTEINS-2 (TRP-2)

ACTIVITY ASSESSMENT

The supernatant obtained from the lysis treated cells was mixed with $1 \mathrm{mM}$ phenylthiourea, 2 $\mathrm{mM}$ EDTA and $10 \mathrm{mM}$ sodium phosphate buffer (pH 6.8). DOPAchrome solution containing 1 $\mathrm{mM} L$-DOPA and $2 \mathrm{mM} \mathrm{NaIO}_{4}$, was added into the mixture and incubated at $37^{\circ} \mathrm{C}$ for $2 \mathrm{~h}$. The reduction of DOPAchrome was measured at 490 $\mathrm{nm}$. The reaction mixture with bovine serum albumin instead of the cell supernatant was used as a negative control. The TRP-2 activity was compared with the control and the inhibitory effect was expressed (Kanlayavattanakul et al. 2016) as following;

TRP-2 inhibitory effect $(\%)=\left[\left(\mathrm{TRP} 2_{\text {sample }} / \mathrm{P}_{\text {sample }}\right) /\right.$ $\left.\left(\mathrm{TRP} 2_{\text {control }} / \mathrm{P}_{\text {control }}\right)\right] \times 100$

where $\mathrm{TRP} 2_{\text {sample }}=\mathrm{TRP}-2$ activity of the sample

$\mathrm{TRP}_{\text {control }}=\mathrm{TRP}-2$ activity of the control
$\mathrm{P}_{\text {sample }} \quad=$ Protein content of the sample

$\mathrm{P}_{\text {control }} \quad=$ Protein content of the control

STATISTICAL ANALYSIS

The data are presented as the mean $\pm \mathrm{SD}$, and a one-way ANOVA test was used to evaluate the differences between groups using the program SPSS version 16.0. The level of significance used was $p<0.05$.

\section{RESULTS AND DISCUSSION}

Waste from fruit processing is a potential source of active phenolics, which are valuable raw materials for the healthcare industry (Matharu et al. 2016). Researchers are actively exploring new methods for the valorization of fruit residues into valueadded specialty ingredients, with sustainable waste management being a key benefit (Berto et al. 2015, Jorge et al. 2016, Lourith et al. 2016, Melo et al. 2015, Sung et al. 2015). As Thailand is a major fruit producer and exporter, waste from several economically important fruit types (litchi, rambutan and tamarind) was selected and screened for its potential as a source of safe and efficient actives for application in the cosmetic industry.

\section{STANDARDIZATION OF FRUIT RESIDUE EXTRACTS}

Quantification of levels of active principles in selected fruits was standardized using TPC (Table I), as previously reported (Kanlayavattanakul and Lourith 2012, Kanlayavattanakul et al. 2012, Pongpunyayuen and Lourith 2011). The extraction procedure proved suitable and repeatable, allowing for acceptable quality control (Antignac et al. 2011) at the level required to meet industrial production practice standards. Standardized extracts were subsequently assessed for their efficiency towards superoxide anion radical scavenging. 
TABLE I

TPC, antioxidant and enzyme inhibitory effects of the fruit extracts.

\begin{tabular}{|c|c|c|c|c|c|c|c|}
\hline \multirow[t]{2}{*}{ Sample } & \multirow{2}{*}{$\begin{array}{c}\text { TPC } \\
\text { (g GAE } / 100 \mathrm{~g} \\
\text { extract) }\end{array}$} & \multicolumn{3}{|c|}{ Antioxidant activity $\left(\mathrm{IC}_{50}, \mu \mathrm{g} / \mathrm{ml}\right)$} & \multicolumn{3}{|c|}{ Enzyme inhibitory effect (\%) } \\
\hline & & ABTS & DPPH & $\mathrm{O}_{2}-$ & Elastase & Collagenase & $\begin{array}{c}\text { Tyrosinase } \\
\left(\mathrm{IC}_{50}, \mu \mathrm{g} / \mathrm{ml}\right)\end{array}$ \\
\hline Litchi & $35.91 \pm 2.14$ & $7.14 \pm 0.0^{\mathrm{a}}$ & $2.29 \pm 0.06^{\mathrm{a}}$ & $29.57 \pm 0.30$ & $88.29 \pm 0.25$ & $79.46 \pm 0.92$ & $\begin{array}{c}197.80 \pm \\
1.23^{\mathrm{a}}\end{array}$ \\
\hline Rambutan & $45.87 \pm 0.29$ & $2.92 \pm 0.02^{b}$ & $1.86 \pm 0.06^{\mathrm{b}}$ & $39.49 \pm 0.52$ & $31.08 \pm 0.38$ & $53.99 \pm 6.18$ & $\begin{array}{c}430.84 \pm \\
0.57^{\mathrm{b}}\end{array}$ \\
\hline Tamarind & $39.25 \pm 1.95$ & $3.41 \pm 0.03^{c}$ & $1.44 \pm 0.01^{\mathrm{c}}$ & $27.44 \pm 0.09$ & $35.43 \pm 0.68$ & $57.69 \pm 5.97$ & $96.15 \pm 0.62^{c}$ \\
\hline Vitamin $\mathrm{C}$ & - & $6.35 \pm 0.09^{\mathrm{a}}$ & $3.40 \pm 0.02^{\mathrm{a}}$ & - & - & - & - \\
\hline Kojic acid & - & - & - & - & - & - & $36.50 \pm 0.60^{a}$ \\
\hline Quercetin & - & - & - & $31.88 \pm 0.15$ & - & - & - \\
\hline Ursolic acid & - & - & - & & $81.40 \pm 0.15$ & - & - \\
\hline EGCG & - & - & - & & - & $86.46 \pm 2.20$ & - \\
\hline
\end{tabular}

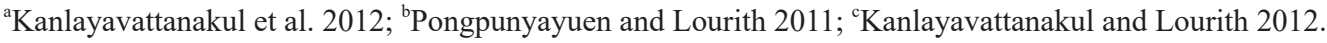

SUPEROXIDE ANION RADICAL SCAVENGING ACTIVITY

Tamarind seed coat extract exhibited significantly $(p<0.05) \mathrm{O}_{2}$ - more potent radical scavenging behavior over other extracts (litchi, rambutan) and that of the standard quercetin (Table I), with similar trends evident for ABTS and DPPH scavenging (Kanlayavattanakul et al. 2012, Kanlayavattanakul and Lourith 2012, Pongpunyayuen and Lourith 2011). Epigallocatechin, the main bioactive in tamarind seed coat material (Kanlayavattanakul and Lourith 2012) has the largest molecular weight of the phenolics discussed here. Previous work has indicated that molecular weight and size of phenolic actives can be an important factor influencing the mechanism of antioxidant activity (Kanlayavattanakul and Lourith 2011a, b). Rambutan peel extract had the highest TPC and was less effective as a radical scavenger, which might be due to the presence of ferulic and gallic acids in its peel (Pongpunyayuen and Lourith 2011), which are smaller phenolic active markers than epigallocatechin in similar with litchi peel extract (Kanlayavattanakul et al. 2012).

\section{ELASTASE INHIBITORY EFFECT}

The ability of extracts to inhibit the elastin degrading enzyme (elastase) was explored at an extract concentration of $0.25 \mathrm{mg} / \mathrm{ml}$, with results compared with those of the standard, ursolic acid $(0.125 \mathrm{mg} / \mathrm{ml})$. Litchi peel extract proved to be significantly more effective $(p<0.05)$ at inhibiting elastase than tamarind seed coat and rambutan peel extracts, as shown in Table I. Doubling the concentration resulted in the elastase inhibition percentage for litchi extract being comparable to that of ursolic acid. Litchi extract showed similar potency against elastase to that of white tea (89\%) and was markedly more potent than green tea, or pomegranate extracts (10 and 15\%), as assessed using the same protocol (Thring et al. 2009).

\section{COLLAGENASE INHIBITORY EFFECT}

Collagenase inhibition by litchi peel extract was highest over the other extract, but significantly ( $p$ $<0.005)$ less potent than the standard (EGCG) at identical concentration $(0.05 \mathrm{mg} / \mathrm{ml})$. Litchi peel extract of each concentration was significantly $(p<0.005)$ more potent than tamarind seed coat and rambutan peel extracts (Table I). In addition, litchi peel extract proved to be more active against 
this enzyme than that of white tea, which only exhibits high collagenase inhibition levels (87\%) at a tested concentration of $0.125 \mathrm{mg} / \mathrm{ml}, 2.5$ times higher than the tested litchi extract concentration. Furthermore, the anti-collagenase activities of all studied extracts were higher than the previously activities reported for green tea and pomegranate extracts (47 and 10\%, respectively) (Thring et al. 2009).

Phenolic was found to be responsible for the anti-elastase and anti-collagenase activities. The structure and nature of phenolics present in an extract influences its biological activity, in particular the mechanisms relating to antioxidant activity (Kanlayavattanakul and Lourith 2012). The extract potency against collagen and elastin degradation tends to be regulated by the content of gallic acid, which is a low molecular weight small phenolic molecule that was shown to be predominant in litchi peel extract (Kanlayavattanakul et al. 2012).

\section{ACTIVITIES IN HUMAN SKIN FIBROBLASTS}

Despite all extracts in this study being proven safe in fibroblasts (Kanlayavattanakul and Lourith 2012, Kanlayavattanakul et al. 2012, Pongpunyayuen and Lourith 2011), no investigations into their cellular activity (anti-aging potential) have been undertaken to date. In this context, the safety profile of all extracts was firstly verified in fibroblasts, with fibroblast cells treated with either vitamin $C$ (the positive control), litchi, rambutan peel, or tamarind seed coat extracts (each $0.1 \mu \mathrm{g} / \mathrm{ml}$ ) showing similar viabilities to that of the cells treated with absolute ethanol (Table II). Litchi extract was shown to be the safest extract, with $0.05,0.01$ and $0.007 \mathrm{mg} / \mathrm{ml}$ being the maximum safe concentrations of litchi, rambutan and tamarind extracts, respectively. In addition, litchi and tamarind extracts were able to promote fibroblast proliferation, and these findings are in accordance with the inhibitory effects of these extracts against elastase and collagenase. These safety concentrations are important indicators in developing treatments using these extracts: the safety profile of these extracts, especially tamarind, need careful consideration.

Assessments of the inhibitory effects of each extract (including vitamin C) against MMP-2 in fibroblasts were investigated in addition to the in vitro cell viability tests, and were measured at their safe doses, as shown in Fig. 1. MMP-2 is an important enzyme catalyzing the degradation of the cellular skin matrix, collagen and elastin (Lourith and Kanlayavattanakul 2016). Assessments of the inhibitory effects of each extract (including vitamin C) against MMP-2 in fibroblasts were measured at their safe doses, as shown in Fig. 1. Vitamin C (standard) inhibited MMP-2 by $10.42 \pm 5.91 \%$ at $0.05 \mathrm{mg} / \mathrm{ml}$, being significantly less potent than litchi $(23.75 \pm 2.74 \% ; p<0.01)$ at the same concentration. The litchi extract inhibitory effect (at $0.05 \mathrm{mg} / \mathrm{ml}$ ) proved comparable to that obtained at the highest safe concentration of rambutan $(0.01$ $\mathrm{mg} / \mathrm{ml}, 23.11 \pm 8.92 \%$ ). In addition, activities against dermal matrix degradation enzyme at 0.007 $\mathrm{mg} / \mathrm{ml}$ indicated that extracts of tamarind and rambutan were significantly more potent $(21.45 \pm$ 5.19 and $17.70 \pm 4.95 ; p<0.002$ and $<0.014)$ than litchi $(7.84 \pm 0.42 \%)$ at this concentration.

\section{ANTI-MELANOGENESIS ACTIVITY IN B16F10 MELANOMA CELLS}

Melanin production is regulated by tyrosinase, and the related proteins TRP-1 and TRP2. Tyrosinase catalyzes the hydroxylation of tyrosine to produce 3,4-dihydroxyphenylalanine (DOPA), and further oxidation of DOPA to form DOPAquinone. Thereafter, TRP-2 functions as a DOPAchrome tautomerase catalyzing the rearrangement of DOPAchrome to 5,6-dihydroxyindole-2-carboxylic acid or DHICA, which is further oxidized by TRP-1 to a carboxylated indole-quinone. Thus, inhibition of melanogenesis regulating enzymes, particularly tyrosinase and 
TABLE II

Safety of the fruit extracts in human skin fibroblast and B16F10 melanoma cells.

\begin{tabular}{|c|c|c|c|}
\hline \multirow[t]{2}{*}{ Sample } & \multirow[t]{2}{*}{ Concentration (mg/ml) } & \multicolumn{2}{|c|}{ Cell viability (\%) } \\
\hline & & Human skin fibroblast & B16F10 melanoma \\
\hline \multirow[t]{8}{*}{ Litchi } & 0.0001 & $94.40 \pm 5.11$ & $104.44 \pm 4.95$ \\
\hline & 0.001 & $89.68 \pm 4.73$ & $105.73 \pm 1.34$ \\
\hline & 0.007 & $100.36 \pm 0.18$ & - \\
\hline & 0.01 & $89.60 \pm 0.83$ & $97.34 \pm 3.16$ \\
\hline & 0.03 & $90.00 \pm 0.69$ & - \\
\hline & 0.05 & $92.45 \pm 0.68$ & - \\
\hline & 0.1 & - & $23.14 \pm 1.48$ \\
\hline & 1 & - & $21.30 \pm 0.35$ \\
\hline \multirow[t]{6}{*}{ Rambutan } & 0.0001 & $100.00 \pm 3.63$ & $96.86 \pm 3.05$ \\
\hline & 0.001 & $92.23 \pm 3.15$ & $93.50 \pm 1.39$ \\
\hline & 0.007 & $94.13 \pm 0.84$ & - \\
\hline & 0.01 & $89.12 \pm 2.26$ & $90.18 \pm 2.35$ \\
\hline & 0.1 & - & $15.39 \pm 0.78$ \\
\hline & 1 & - & $13.69 \pm 0.14$ \\
\hline \multirow[t]{6}{*}{ Tamarind } & 0.0001 & $101.56 \pm 0.52$ & $99.15 \pm 3.06$ \\
\hline & 0.001 & $97.93 \pm 1.80$ & $98.19 \pm 0.58$ \\
\hline & 0.007 & $110.46 \pm 3.40$ & - \\
\hline & 0.01 & - & $18.85 \pm 0.67$ \\
\hline & 0.1 & - & $16.54 \pm 0.43$ \\
\hline & 1 & - & $14.23 \pm 0.19$ \\
\hline \multirow[t]{3}{*}{ Vitamin C } & 0.01 & $95.22 \pm 2.79$ & - \\
\hline & 0.03 & $100.00 \pm 4.44$ & - \\
\hline & 0.05 & $108.37 \pm 0.80$ & - \\
\hline
\end{tabular}

TRP-2, is therefore a focal point for research into preventing skin hyperpigmentation, a clinical sign of cutaneous aging (Kammeyer and Luiten 2015).

In vitro tyrosinase activity assays indicate that tamarind seed coat extract is the most potent inhibitor than litchi, and rambutan peels (Table I). However, anti-melanogenesis activities for these extracts in cell cultures have not been reported previously. Thus, safety profiles, and a clear understanding of their modes of action in cellular studies were necessary to be examined.

Safety profiles for all extracts were examined in B16F10 melanoma cells, which are widely used in melanin biosynthesis studies (Sung et al. 2015). Litchi and rambutan extracts proved to be safe at
$0.0001-0.01 \mathrm{mg} / \mathrm{ml}$ concentrations, with tamarind extract having a maximum safe concentration of $0.001 \mathrm{mg} / \mathrm{ml}$ (Table II). Accordingly, the impact of extracts on melanin production was assessed at these concentrations.

Melanoma cells were induced to synthesize melanin using theophylline $(\mathrm{T})$, the positive control. Kojic acid (KA) was used as the negative control, suppressing melanin synthesis. $\mathrm{T}$ induces melanogenesis through the cAMP-dependent signaling pathway, with an induction of gammaglutamyl transpeptidase-, and tyrosinasereactive cells enhancing the melanin content to a level of $137.71 \pm 2.70 \%$. By comparison, KA, a melanogenesis inhibitor, chelates with 


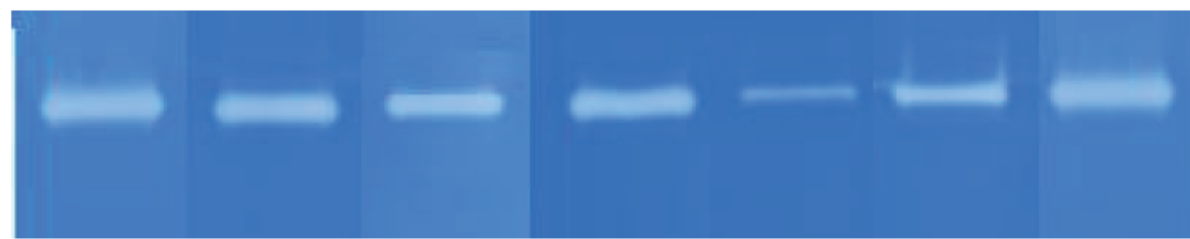

Sample *

Control

LC

NL

TI Vit. C

Concentration $(\mathrm{mg} / \mathrm{ml})$

$0.007 \quad 0.05$

0.007

0.01

0.007

0.05
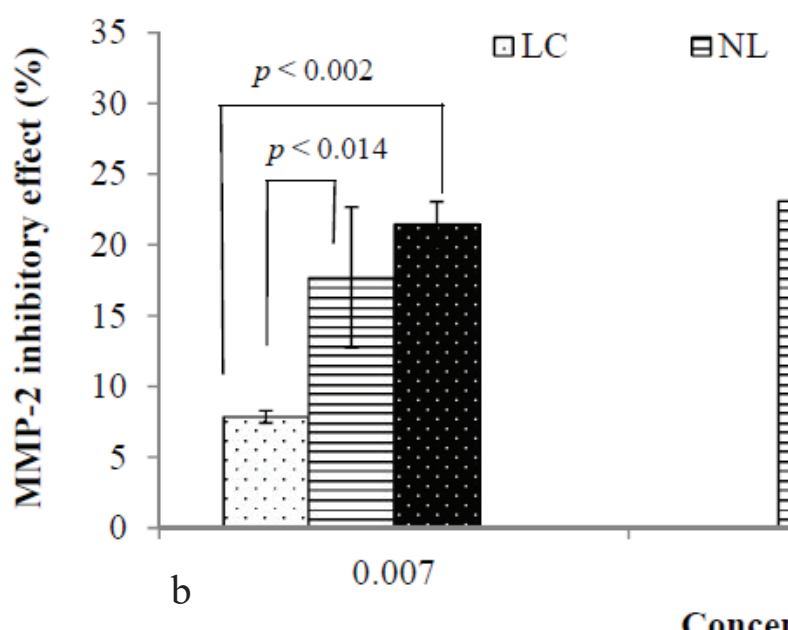

Conc
C.
tion of

DOPAchrome to 5,6-dihydroxyindole-2-carboxylic acid (an intermediate in the melanin synthesis pathway and common skin lightening agent) (Kim et al. 2012), resulting in a $72.55 \pm 3.78 \%$ melanin production level (Fig. 2a). Inhibitory effects of extracts followed a dose dependent profile with tamarind extract being the most potent at suppressing melanin production (Fig. 2b) with the calculated cellular $\mathrm{IC}_{50}$ of $0.019,0.040$ and $0.077 \mathrm{mg} / \mathrm{ml}$ for tamarind, rambutan and ltichi, respectively. Notably, litchi extract significantly $(p<0.05)$ better suppressed melanin production $(67.84 \pm 4.75 \%)$ than kojic acid $(72.55 \pm 3.78 \%)$ at $0.05 \mathrm{mg} / \mathrm{ml}$. In addition, litchi extract was shown to be more potent than spent coffee $(21 \%$ at $0.1 \mathrm{mg} /$ $\mathrm{ml}$ ) as obtained from a more efficient extraction protocol that previously reported (Sung et al. 2015).

Tyrosinase inhibitory assays with melanoma cells indicated that treatment with $\mathrm{T}$ resulted in enhanced activity $(126.51 \pm 0.82 \%)$, whereas KA treatment resulted in down-regulation. In a similar trend to that seen in the melanin content assay, the extracts inhibited tyrosinase activity by a greater extent at higher doses. Surprisingly, litchi extract showed significantly $(p<0.01)$ stronger tyrosinase inhibition activity over that of kojic acid at the same concentration $(77.15 \pm 2.05$ and $29.79 \pm 5.42 \%$ at $0.05 \mathrm{mg} / \mathrm{ml}$ ), as shown in Fig. 3. Moreover, litchi peel extract proved to be a stronger tyrosinase inhibitor than spent coffee $(33.5 \%$ at $0.1 \mathrm{mg} / \mathrm{ml})$ (Sung et al., 2015). In addition, TRP-2 activity was down-regulated on treatment with the fruit residue 
a

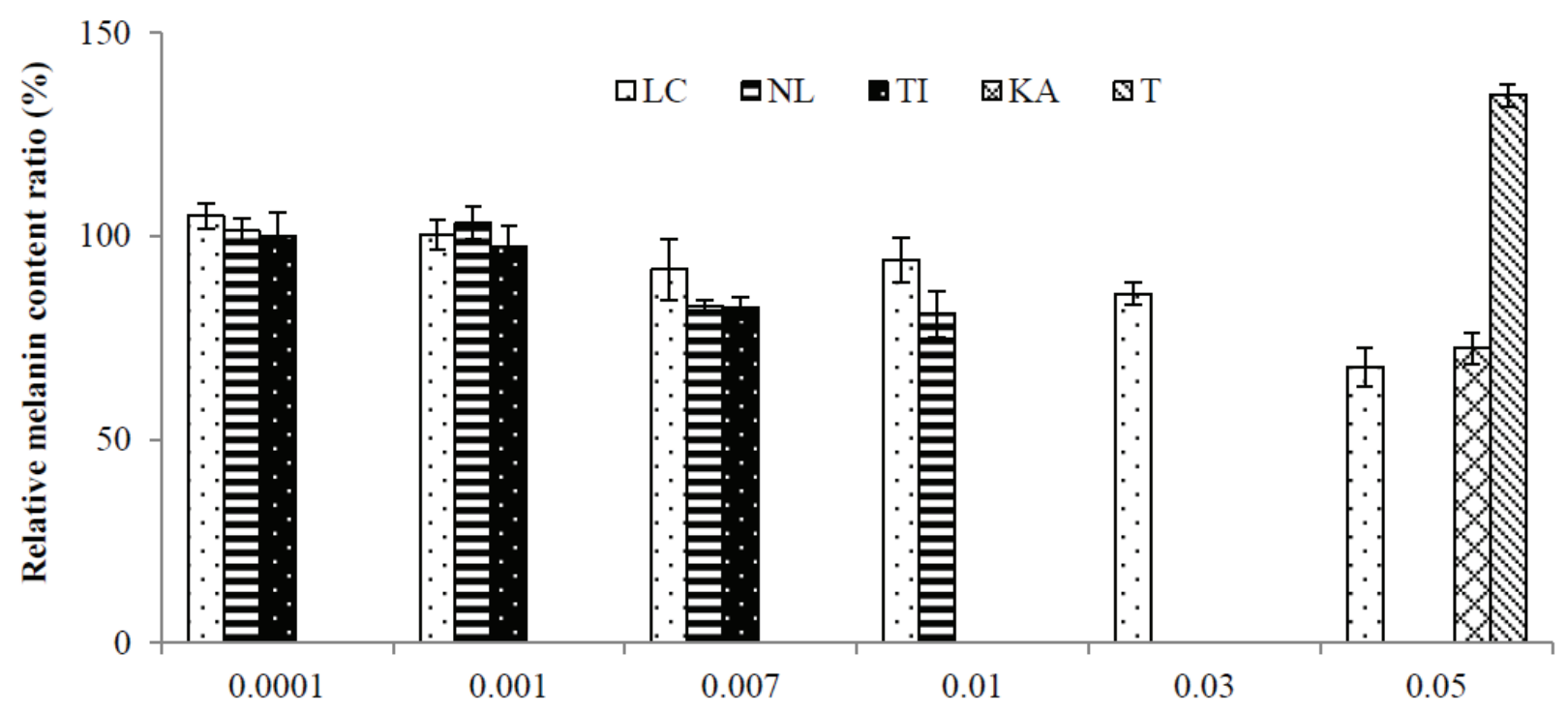

Concentration $(\mathrm{mg} / \mathrm{ml})$

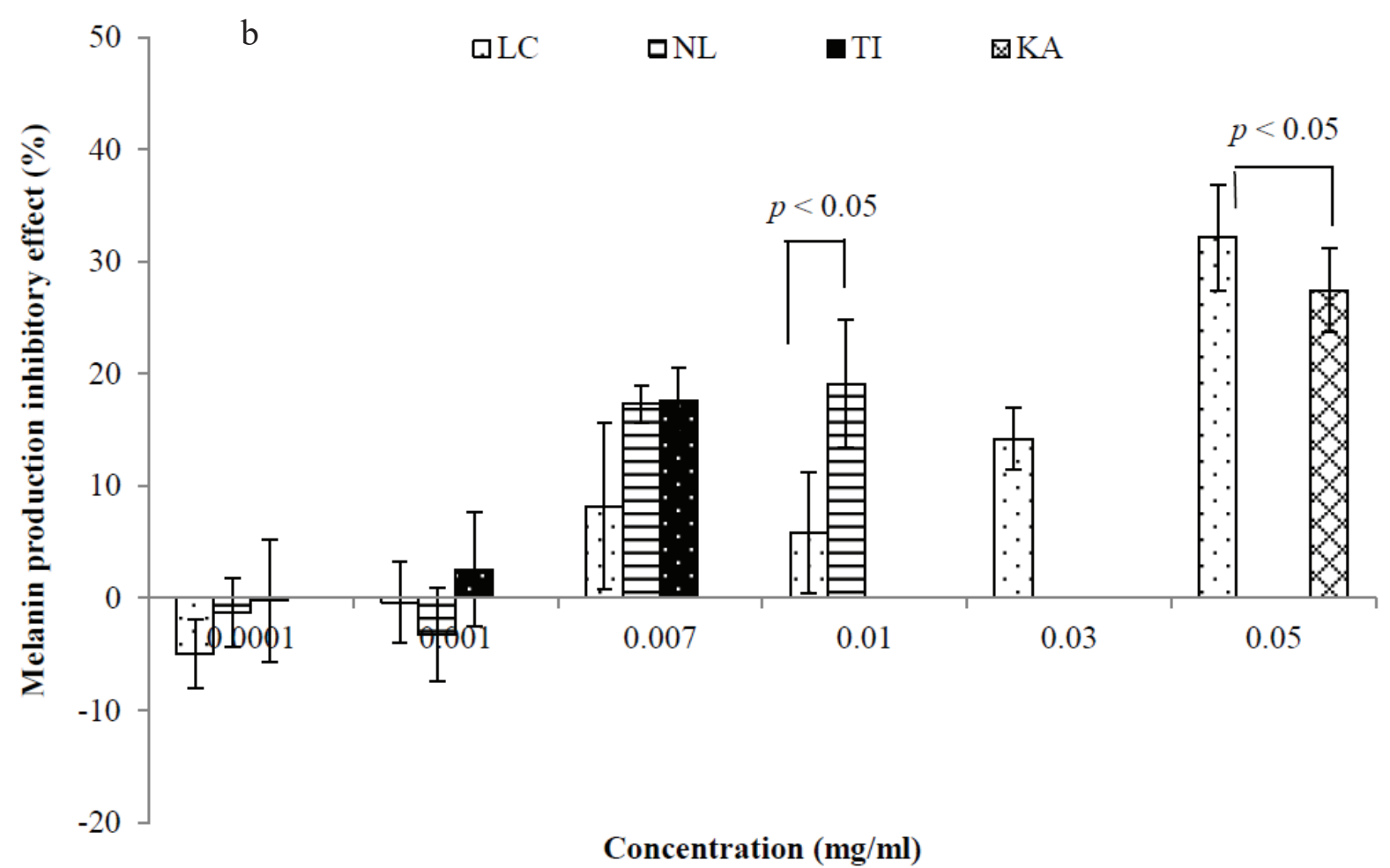

Figure 2 - The fruit extracts' activity against melanin production in B16F10 melanoma cells (a) and their inhibitory effects (b). $* \mathrm{LC}=$ Ltichi; $\mathrm{NL}=$ Rambutan; $\mathrm{TI}=$ Tamarind and $\mathrm{KA}=$ Kojic acid. 


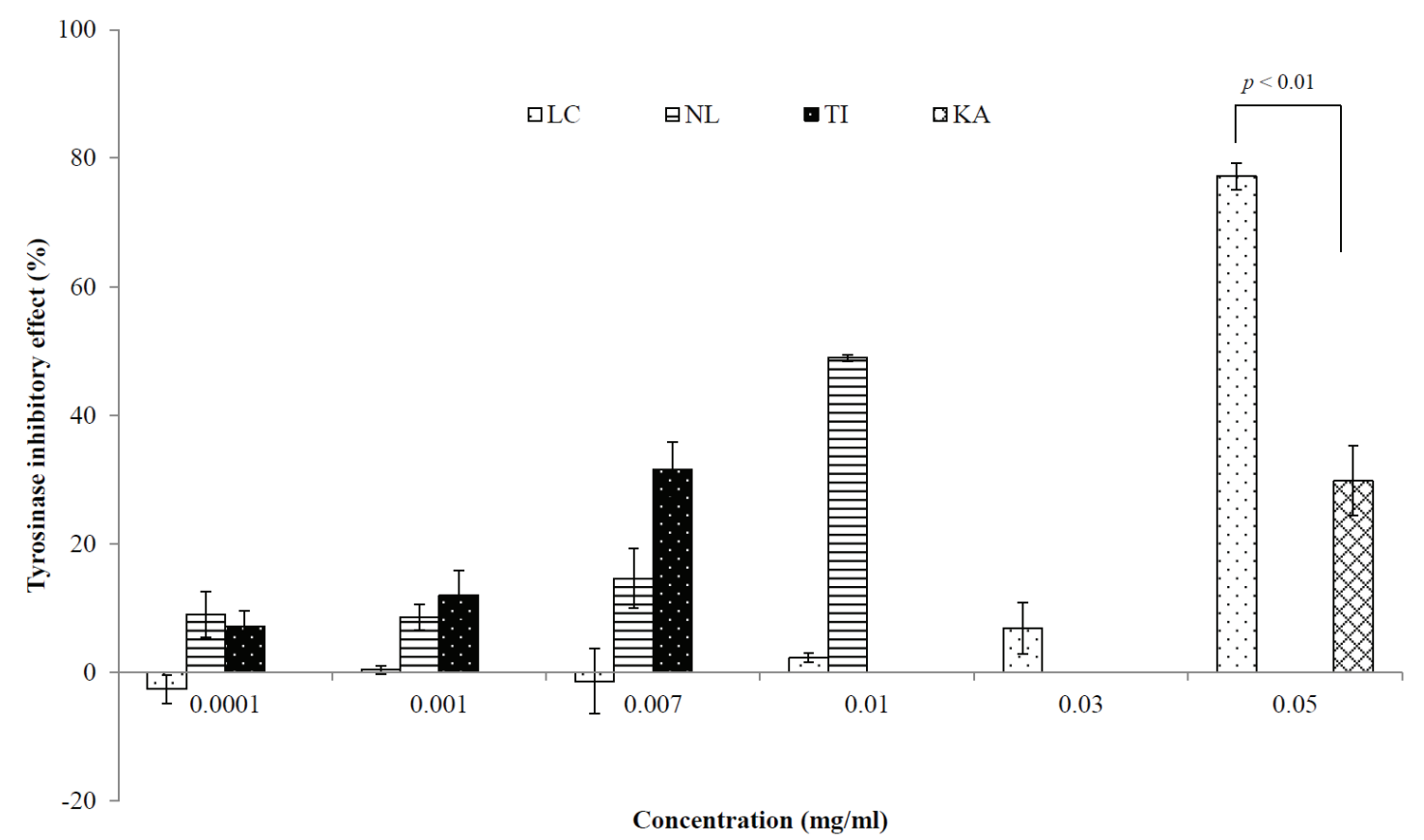

Figure 3 - The fruit extracts' activity against tyrosinase in B16F10 melanoma cells. *LC = Ltichi; NL= Rambutan; TI $=$ Tamarind and $\mathrm{KA}=$ Kojic acid.

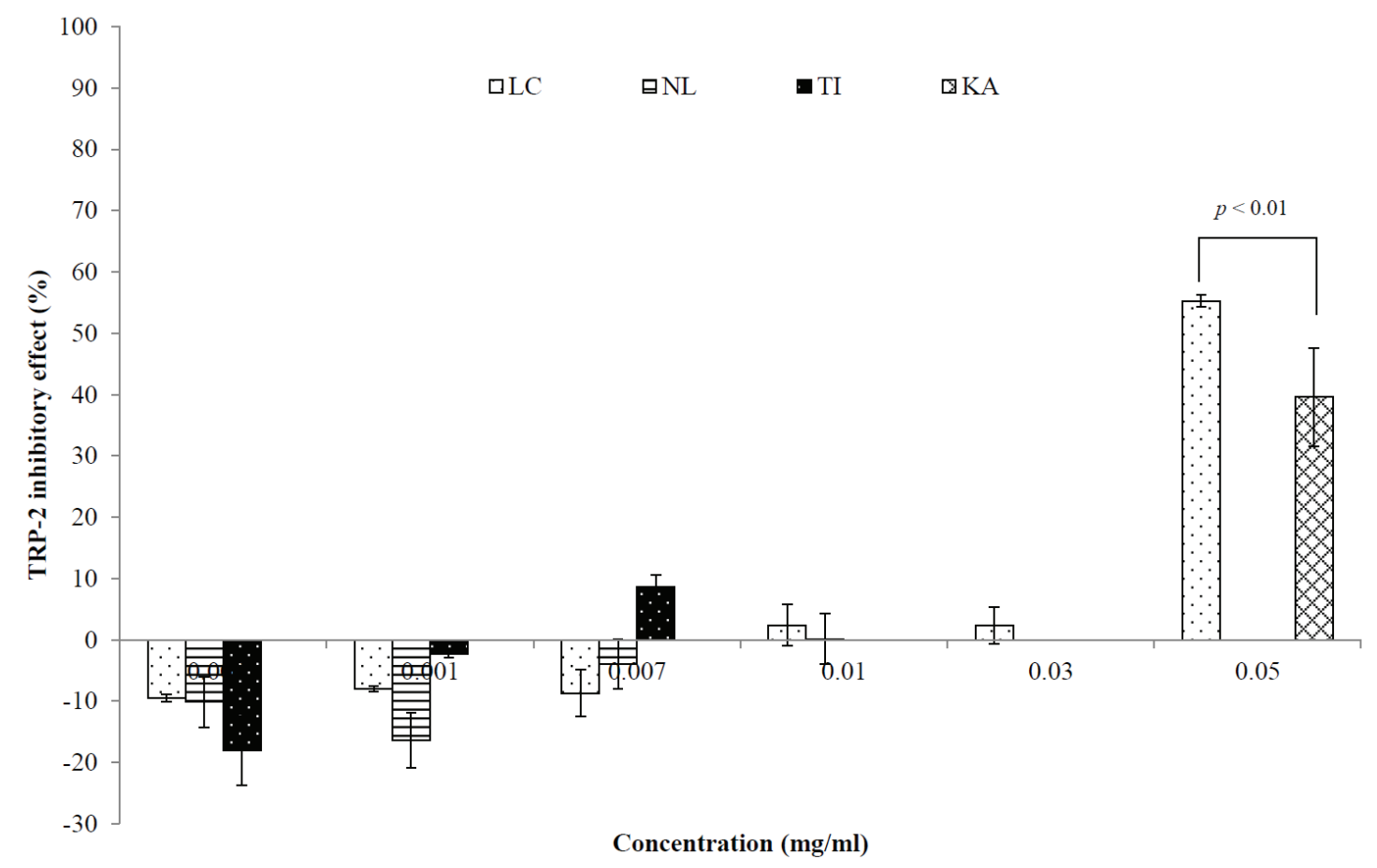

Figure 4 - The fruit extracts' activity against TRP-2 in B16F10 melanoma cells. ${ }^{*} \mathrm{LC}=$ Ltichi; NL $=$ Rambutan; TI = Tamarind and KA = Kojic acid. 
extracts, as shown in Fig. 4, with the extent of TRP2 inhibition being in accordance with the extracts' anti-tyrosinase activities. In summary, treatment with litchi extract resulted in significant $(p<0.01)$ suppression of TRP-2 activity (55.26 $\pm 1.01 \%)$ over that of kojic acid $(39.60 \pm 7.98 \%)$ at the same concentration $(0.05 \mathrm{mg} / \mathrm{ml})$.

\section{CONCLUSIONS}

Standardized extracts of fruit residues (litchi and rambutan peel, and tamarind seed coat) were prepared, with TPC being successfully employed to monitor quality control. Tamarind extract significantly quenched $\mathrm{O}_{2}{ }^{--}$to a greater extent than other extracts, including quercetin (standard). Litchi extract proved the most potent inhibitor of elastase and collagenase, followed by tamarind and rambutan extracts. All extracts were shown to be safe in human skin fibroblasts, and result in efficient protection from oxidative damage, and the action of MMP-2. In addition, extracts were exhibited to lighten skin via melanogenesis suppression, arising from tyrosinase and TRP-2 inhibitory effects. From these studies, and their maximum safe concentrations, litchi peel extract appears to be the most promising candidate for incorporation into anti-aging and skin lightening cosmetic products. These results give credence to the idea of value creation from waste, with biologically active phenolics from fruit wastes being of great potential as additives or specialty ingredients for personal care products.

\section{ACKNOWLEDGMENTS}

The authors acknowledge Assoc. Prof. Dr. Nijsiri Ruangrunsri for identification of plant materials. This research was financially supported in part by the office of the National Research Council of Thailand (FY 2013 and FY 2016) grant no. 56208000520 and 59208040011. The reviewers are deeply acknowledged on their valuable suggestions that make the article more comprehensive.

\section{REFERENCES}

ANTIGNAC E, NOHYNEK GJ, RE T, CLOUZEAU J AND TOUTAIN H. 2011. Safety of botanical ingredients in personal care products/cosmetics. Food Chem Toxicol 49: 324-341.

BERTO A, RIBEIRO AB, DE SOUZA NE, FERNANDES E AND CHISTÉ RC. 2015. Bioactive compounds and scavenging capacity of pulp, peel and seed extracts of the Amazonian fruit Quararibea cordata against ROS and RNS. Food Res Int 77: 236-243.

HAKIME-SILVA RA, VELLOSA JCR, KHALIL NM, KHALIL OAK, BRUNETTI IL AND OLIVEIRA OMMF. 2013. Chemical, enzyme and cellular antioxidant activity studies of Agaricus blazei Murrill. An Acad Bras Cienc 85: 1073-1081.

HERRING T AND JUNG K. 2012. The radical status factor (RSF): a novel metric to characterize skin products. Int Cosmet Sci 34: 285-292.

JORGE N, DA SILVA AC AND ARANHA CPM. 2016. Antioxidant activity of oils extracted from orange (Citrus sinensis) seeds. An Acad Bras Cienc 88: 951-958.

KAMMEYER A AND LUITEN RM. 2015. Oxidation events and skin aging. Ageing Res Rev 21: 16-29.

KANLAYAVATTANAKUL M AND LOURITH N. 2011a. Sapodilla seed coat as a multifunctional ingredient for cosmetic applications. Process Biochem 46: 2215-2218.

KANLAYAVATTANAKUL M AND LOURITH N. 2011b. Therapeutic agents and herbs in topical application for acne treatment. Int J Cosmet Sci 33: 289-297.

KANLAYAVATTANAKUL M AND LOURITH N. 2012. Biologically active phenolics in seed coat of three sweet Tamarindus indica varieties grown in Thailand. Adv Sci Eng Med 4: 511-516.

KANLAYAVATTANAKUL M AND LOURITH N. 2015. An update on cutaneous aging treatment using herbs. J Cosmet Laser Ther 17: 343-352.

KANLAYAVATTANAKUL M, LOURITH N AND CHAIKUL P. 2016. Jasmine rice panicle: A safe and efficient natural ingredient for skin aging treatments. J Ethnopharmacol 193: 607-616.

KANLAYAVATTANAKUL M, OSPONPANT D, RUKTANONCHAI U AND LOURITH N. 2012. Biological activity assessment and phenolic compounds characterization from the fruit pericarp of Litchi chinensis for cosmetic application. Pharm Biol 50: 1384-1390.

KIM H, CHOI HR, KIM DS AND PARK KC. 2012. Topical hypopigmenting agents for pigmentary disorders and their mechanisms of action. Arch Dermatol 24: 1-6. 
LOURITH N AND KANLAYAVATTANAKUL M. 2016. Biopolymeric agents for skin wrinkle treatment. J Cosmet Laser Ther 18: 301-310.

LOURITH N, KANLAYAVATTANAKUL M AND CHANPIROM S. 2009. Free radical scavenging efficacy of Tamarind seed coat and its cosmetics application. J Health Res 23: 159-162.

LOURITH N, KANLAYAVATTANAKUL M, MONGKONPAIBOOL K, BUTSARATRAKOOL T AND CHINMUANG T. 2016. Rambutan seed as a new promising unconventional source of specialty fat for cosmetics. Ind Crops Prod 83: 149-154.

MANOSROI A, JANTRAWUT P, AKIHISA T, MANOSROI W AND MANOSROI J. 2011. In vitro and in vivo skin anti-aging evaluation of gel containing niosomes loaded with a semi-purified fraction containing gallic acid from Terminalia chebula galls. Pharm Biol 49: 1190-1203.

MATHARU AS, DE MELO EM AND HOUGHTON JA. 2016. Opportunity for high value-added chemicals from food supply chain wastes. Bioresour Technol 215: 123-130.

MELO PS, MASSARIOLI AP, DENNY C, DOS SANTOS LF, FRANCHIN M, PEREIRA E, DE SOUZA VIEIRA TMF, ROSALEN PL AND DE ALENCAR SM. 2015.
Winery by-products: extraction optimization, phenolic composition and cytotoxic evaluation to act as a new source of scavenging of reactive oxygen species. Food Chem 181: 160-169.

PONGPUNYAYUEN P AND LOURITH N. 2011. Radical scavenging activity and phenolic compounds in rambutan peels extracts. In: PACCON 2011 CONFERENCE. Bangkok, Thailand, January, p. 5-7.

RANIC M, NIKOLIC M, PAVLOVIC M, BUNTIC A, SILERMARINKOVIC S AND DIMITRIJEVIC-BRANKOVIC S. 2014. Optimization of microwave-assisted extraction of natural antioxidants from spent espresso coffee grounds by response surface methodology. J Clean Prod 80: 69-79.

SARIN T, KANLAYAVATTANAKUL M AND LOURITH N. 2013. Neuritogenic and neuroprotective activities of fruit residues. Nat Prod Commun 8: 1583-1586.

SUNG HM, JUNG HJ, SIN JS, KIM KM AND WEE JH. 2015. Skin whitening activity of supercritical fluid extract from spent coffee in B16F10 melanoma cell. Food Sci Biotechnol 24: 1087-1096.

THRING TSA, HILI P AND NAUGHTON DP. 2009. Anticollagenase, anti-elastase and anti-oxidant activities of extracts from 21 plants. BMC Comp Alt Med 4: 9-27. 